\title{
Labour market information for educational investments
}

Citation for published version (APA):

Heijke, J. A. M. (1996). Labour market information for educational investments. Researchcentrum voor Onderwijs en Arbeidsmarkt, Faculteit der Economische Wetenschappen. ROA Working Papers No. 2E https://doi.org/10.26481/umarow.199602E

Document status and date:

Published: 01/01/1996

DOI:

10.26481/umarow.199602E

Document Version:

Publisher's PDF, also known as Version of record

\section{Please check the document version of this publication:}

- A submitted manuscript is the version of the article upon submission and before peer-review. There can be important differences between the submitted version and the official published version of record.

People interested in the research are advised to contact the author for the final version of the publication, or visit the DOI to the publisher's website.

- The final author version and the galley proof are versions of the publication after peer review.

- The final published version features the final layout of the paper including the volume, issue and page numbers.

Link to publication

\footnotetext{
General rights rights.

- You may freely distribute the URL identifying the publication in the public portal. please follow below link for the End User Agreement:

www.umlib.nl/taverne-license

Take down policy

If you believe that this document breaches copyright please contact us at:

repository@maastrichtuniversity.nl

providing details and we will investigate your claim.
}

Copyright and moral rights for the publications made accessible in the public portal are retained by the authors and/or other copyright owners and it is a condition of accessing publications that users recognise and abide by the legal requirements associated with these

- Users may download and print one copy of any publication from the public portal for the purpose of private study or research.

- You may not further distribute the material or use it for any profit-making activity or commercial gain

If the publication is distributed under the terms of Article $25 \mathrm{fa}$ of the Dutch Copyright Act, indicated by the "Taverne" license above, 


\section{Labour Market Information for}

Educational Investments

ROA-W-1996/2E

Hans Heijke

Research Centre for Education and the Labour Market

Faculty of Economics and Business Administration

University of Limburg

Maastricht, March 1996 
ISBN 90-5321-178-0 


\section{Contents}

Page

Abstract

1 Introduction 1

2 Some policy approaches in brief 4

3 The importance of labour market information: the situation in the Netherlands 6

$\begin{array}{ll}3.1 \text { For those choosing an educational course } & 6\end{array}$

3.2 For other interested parties 8

3.3 More stable flows into the education system 10

4 Labour market theory and labour market information 12

4.1 Various theoretical visions $\quad 12$

4.2 Human capital theory 13

4.3 The screening hypothesis 15

4.4 The labour queue theory 16

4.5 The job matching theory 16

4.6 The segmentation theory 17

5 What labour market information is required? 18

6 Labour market forecasts $\quad 20$

6.1 Basic principles 20

6.2 ROA's approach 21

7 A European approach $\quad 25$

$\begin{array}{ll}\text { References } & 25\end{array}$ 


\begin{abstract}
A well-trained workforce is generally seen as an important precondition for economic growth. But decisions about investments in education and training must be taken under uncertainty, because the benefits will only be reaped in the long term. To predict what these future benefits may be, it is necessary to have some insight into how the labour market functions with respect to education and training.

There are various theories, in the literature, which outline a picture of the role played by education and training in the labour market. This paper begins with a sketch of the various policy approaches to the match between the education system and the labour market and an explanation of the importance of labour market information for policy choices. Five labour market theories in which workers' educational backgrounds is an important factor will be described. Then, on the basis of these theories, we infer what labour market information could be significant in educational decisions. Some basic principles for the preparation of labour market forecasts are identified, and a structure which could be used in making forecasts is outlined. The paper concludes with a plea for a European approach.
\end{abstract}




\section{Introduction ${ }^{1}$}

A well-trained workforce is generally seen as an important precondition for achieving economic growth. But a workforce with higher education does not necessarily imply higher economic growth. The productive value of education is in fact dependent not only on the level of the education but also on the subjects studied, and on which occupation is practised with that education. Moreover, educating the population requires educational facilities, which must be provided with resources which are then denied to other productive purposes.

The great diversity of types of education and occupations means that optimalizing the contribution of education to economic growth involves solving a complex tuning problem in the labour market. In a perfectly operating labour market, equilibrium would be achieved automatically. In practice the functioning of the labour market is obstructed by a wage structure which is relatively inflexible, limited opportunities for substitution between submarkets, high adjustment costs, the existence of various institutions intended to provide protection and security and the limited transparency of market events for all those who are involved. This paper focuses especially on the last of these imperfections. It will show what labour market information would increase the transparency of the labour market for those with an interest in investment in education.

A particular problem in seeking to increase the transparency of the labour market for both students and educational decision-makers is that the benefits of educational investments only become evident in the future. Thus the optimalization of training decisions is dependent on estimates of future situations. For various reasons this is a difficult matter.

The first difficulty is that the productive yield of a training course is difficult to isolate from other influences on the productivity of a worker. It may be that a 'productive' training course is in fact one which attracts students who already possessed skills which were relevant to the practice of the occupation. ${ }^{2}$ Another measuring problem is that the human capital built up in initial education undergoes various changes after entry to the labour market. Many of these changes are difficult to measure, such as the increase in knowledge and skills as a result of increased experience in successive jobs and of various forms of training within or outside the firm, or equally the loss of knowledge and skills which results from disuse in the event of unemployment or underutilization and from physical aging and economic obsolescence.

1. A previous version of this paper was presented at the ECE/Eurostat Joint Work Session on Demographic Projections, Mondorf-les-Bains, Luxembourg, 1-4 June 1994. The author would like to thank Andries de Grip for reading an earlier version of the text at hand and providing some suggestions for improvements.

2. For an econometric approach to the problem of self-selection in the choice of training courses, see Willis and Rosen, 1979. 
It is not only the actual amounts of human capital which determine the productive returns on training. As noted at the outset, the specific occupations in which this capital is set to work are also important. According to the 'job matching' theory individuals who have certain characteristics, including educational attainment, have comparative advantages in performing occupations with certain characteristics (Sattinger, 1975; Jovanovic, 1979). Productivity in a given occupation is thus the result of the interaction between the occupation and the person filling the occupation. In tracing the specific effect of education and training on productivity it is usual to estimate wage functions, which incorporate these and other influences (Mincer, 1974; Hartog 1985; Koopmans, Van Opstal and Theeuwes, 1989). This approach involves the heroic assumption that pay is equal to the marginal productivity of labour, although there is evidence that the productivity effect of training is greater than the wage effect (De Koning and Gelderblom, 1992). The estimation of wage functions moreover requires very specific data-bases, which, even where they are available, do not as a rule give a complete picture of the pay situation over the full width of the labour market, with all the necessary differentiations by age, gender, educational background, experience, occupation and branch of industry.

The second difficulty in indicating the future labour market situation for training types is the lack of a coherent conception of the way in which the labour market functions and the specific ways in which the relation between the education system and the labour market is established. There is thus some doubt as to exactly which theories or aspects of theories are most valid. For example, there is no general consensus about the empirical relevance of theories which are discussed in the literature, such as the human capital theory, the screening theory, the theory of the labour queue, the job matching theory and the segmentation theory. In extrapolating the current trends in the labour market into the future with the aid of models, it is however necessary to be able to state explicitly how the various socio-economic variables relate to one another. This will entail facing the problem that labour market theories often build on the neo-classical assumption of a flexible and balanced labour market, an assumption which is of limited use for empirical models of the labour market process.

The third difficulty follows from the second. Even if one knew exactly how the labour market functions, there is always uncertainty as to what conditions outside the labour market, which could have a decisive influence on labour market relations in the future, must be taken into account in extrapolating labour market developments. Demographic growth, technological progress and the uncertain developments on the national and international markets of other production factors and those for goods and services, are some factors that come to mind.

Despite the difficulties outlined here, attempts have been made in recent decades, with varying success, to get a better insight into the prospects for finding or keeping a job of those having particular types of training, or, to put it differently, what are the prospects of satisfying employers' needs for workers with a particular educational background. One of the best known of these attempts is the Occupational Outlook Handbook, with information on about 200 occupations, which is published in an updated form every two years by the Bureau of Labor Statistics (BLS) of the U.S. Department of Labor. This handbook provides data on the characteristics of each of these occupations and their career opportunities, wages and labour market prospects in the long term. The Dutch Research Centre for Education and the Labour Market (ROA), which is affiliated to the University of Limburg in Maastricht, was established in 1986 to provide a similar service. To this end, ROA has developed the Information System on Education and the Labour Market. In comparison to the handbook of the BLS, this system is more focused on providing quantitative information on the 
labour market prospects of graduates from particular types of education. However the forecast data is limited, for the present, to the medium term, i.e., to a forecast period which is most relevant for those making study choices and who want to know what their chances are of finding a job after completing a course. The Information System on Education and the Labour Market is integrated within the Traject series, a series of information systems on CD-rom intended for those facing vocational and educational choices. This series is commercially exploited by the National Career Guidance Information Centre (LDC). The Traject series also includes a great variety of detailed further information on types of educations and the characteristics of occupations, so that together the breadth of information supplied is equal to, or even greater than, that offered in the BLS handbook.

Other examples are the Institute for Employment Research of the University of Warwick in Coventry and the Institut für Arbeitsmarkt- und Berufsforschung, of the Bundesanstalt für Arbeit, in Nuremberg. The forecasting activities of the three European institutes for labour market research are described in detail in Heijke (1994). This book also gives information on how labour market forecasts are compiled, a question which can only be outlined here in general terms. This paper is limited to a more basic question underlying these forecasts: what labour market information is relevant for facilitating decisions on investments in education? The various labour market theories will be consulted for the inspiration they can offer in answering this question. The discussion will be limited to the role of initial education, because educating young people during their initial education is a longterm investment which lays the foundation for their later opportunities for development, and subsequent training during their working lives will generally be shorter and serves principally as a supplement, aiming at better performance in a given occupation or function. The practical possibilities of increasing the transparency of the labour market for educational investment decisions will be illustrated using the example of ROA's Information System on Education and the Labour Market. Since the progressive integration of Europe will also entail the internationalisation of the labour market, the last part of this paper will present some remarks about this.

The remainder of this paper is structured as follows. Section 2 outlines a number of policy approaches which have been taken since the 60 s to improve the match between the education system and the labour market. These are the manpower requirements approach, the flexibility approach and, more recently, the market transparency approach, which sees the role of forecasting as a tool to improve transparency. In the context of the transparency approach, Section 3 examines the more specific interests of the various parties in the Netherlands who are involved in educational investment in having access to adequate labour market information. The transparency of the labour market will not be increased by the haphazard collection of data, but rather by generating information based on a systematic concept of the functioning of the labour market. Therefore section 4 discusses the five labour market theories mentioned above, which can serve as starting-points in forming such a systematic picture. On the basis of this theoretical survey, Section 5 gives an overview of the information which would be required to make the labour market more transparent for those who are involved in or affected by educational investments. Because the effects of an educational investment will only be realized in the future, when the graduates have entered the labour market, labour market forecasts must be made available. Section 6 presents some fundamental principles and outlines a structure for preparing labour market forecasts. The paper concludes with section 7 , which argues for a European approach to achieving a transparent labour market for decisions concerning educational investments. 


\section{Some policy approaches in brief}

In the past it was thought that the problem of coordination between the education system and the labour market could be solved by planning. One well-known approach is that of Parnes (1962), who developed a manpower requirements model on the basis of the input-output structure of the economy. The planning begins with the determination of the target growth in the Gross National Product over a period of several years. From this, after a number of steps, the labour requirements in the various occupations and the educational qualifications which are required for these occupations are determined. The labour requirements are then compared with forecasts of the working population and the flow of graduates from the various types of training onto the labour market. The graduateflow forecasts are compiled with the aid of a student-flow model that describes the flows of students within the educational system. From the differences between future labour requirements and the future working population, allowing for the expected flows from the educational system, it is possible to extract the required information on the extra training initiatives which are needed to achieve the desired growth in the Gross National Product.

Various methodological and fundamental objections have been made to the manpower requirements approach. The methodological objections focus particularly on the fixed coefficients, which are used in the forecasting models to translate economic development into changes in employment differentiated by training and occupation, and on its mechanical concept of labour market functioning, in which there is no place for the working of substitution and other adjustment processes (Blaug, 1967). The fundamental objections are that future developments are not in fact sufficiently predictable, and that an exclusive relationship between job requirements and training is assumed without adequate justification.

These objections, and the lack of sufficient statistical data for the estimation of the forecasting models, led to the rejection of the planning concept. A flexible approach to education was advocated, through which uncertain future developments could be responded to adequately (for a Dutch example see Van Hoof and Dronkers, 1980). According to the latter concept, initial training courses should be broadened so that each could lead to a broad range of occupations. Any discrepancies which might arise between specific, and mutable, job demands and the qualifications of workers would have to be dealt with by means of short training courses and on-the-job training.

The broader scope of initial training courses would speed the matching process in the external labour market, which would lower the search costs for both sides of the market, with the ultimate result that the visible surpluses and shortages of workers with a particular educational background should become smaller. However, if all graduates were to find the job which corresponded best to their comparative advantages, the less vocation-specific character of these training courses would also result in a poorer average match between the occupation-specific job requirements and the knowledge and skills of those filling the jobs, which would lead to lower productivity in carrying out their functions. Increased market efficiency is thus achieved at the price of reduced economic effectiveness. In such a situation one has to seek the optimal trade-off between flexibility and productivity (De Grip and Heijke, 1991). The flexibility concept would thus have to be implemented within certain limits, meaning that optimal labour market relations would not exclude a degree of market segmentation by training and occupation. The rigidity of the relative wage rates, the high cost of adjustment and the long time required for the supply of labour to adapt to changes in demand, because of the length of training courses in initial education, would in this situation continue to be an 
impediment to the achievement of a perfect match between demand and supply.

As a result of the failings of the macro-economic policy that was put into place to counter the results of the oil crisis in the 70s, there has been more interest in improving the adaptability of the supply side of the economy. The process of industrial restructuring and renewal had to be promoted and the working of the market generally stimulated. It was no longer thought that a policy of direct intervention was required to ensure the correspondence of the education system to the labour market, but rather that the provision of adequate information would make the labour market more transparent for those choosing a course of study and others investing in education. This transparency would perhaps make the supply of labour more responsive to changes on the labour market. It would then automatically conform better to the new employment opportunities.

\section{The importance of labour market information: the situation in the Netherlands}

\subsection{For those choosing an educational course}

This subsection will examine whether students in the Dutch educational system actually weigh labour market factors when making their educational choices, using the results from some previous studies. Research in the Netherlands has shown that secondary and tertiary students have at least some interest in the labour market implications when they are choosing a course of study or occupation. A study by Kodde and Ritzen (1986), for example, shows that, for students from the second phase of secondary education, the chances of getting a job and being able to practise a particular occupation are important motives in deciding whether or not to go further with their study. Earnings prospects, however, appeared to be given less weight. ${ }^{3}$ These results have been substantially confirmed by Herweijer and Blank (1987), whose research found a significant positive correlation between unemployment and the numbers going on to further education. From these results one would conclude that further study is to some extent seen as a way to avoid unemployment, and that people expect that gaining a higher diploma will increase their chances on the labour market.

Recently, results from an extensive study of high school graduates from the various parts of the Dutch secondary education system have become available (De Jong et al., 1992). The research provides information on the nature of the choices which students make as regards their further educational or occupational careers, and the motives behind these choices. The results of this research show, among other things, that the study plans of students have little relation to their social backgrounds. Important motives for going further with education, along with 'utilizing talents and selfdevelopment', include a number of considerations relating to possibilities in the future, such as 'to gain a higher position', 'more chance of getting a job' and 'high income'.

3. Nevertheless, a later study by Oosterbeek and Webbink (1995) using the same data from 1982 and a similar set of data from 1991 has shown that future income does play a role in the decision to undertake higher education (for the 1991 data, see also De J ong et al. (1992). 
All these studies say something about the role of the labour market in making choices about continuing education. Unfortunately there is less information available regarding the role of labour market expectations in choosing a particular course of study. There are however a number of studies which give us some indications. In their inventory of previous research, Verrijdt and Diederen (1987) found that the regional employment structure had an influence on the actual school choice and occupational choice of ex-students in Junior Technical Secondary Education and Junior General Secondary Education. A study by Willems and de Grip (1994) of the motives underlying general secondary school students' decisions to continue in further education in a technical field showed that the images which young people have of both the labour market position of these studies and the qualitative aspects of the work are important in the choices they make. Another indication can be found in Pater's research (1987) among graduates from Junior and Senior General Secondary Education and University Preparatory Education. This research shows that these graduates did have an idea, although a very subjective one, of the future importance of a number of branches of industry, and that this picture had played a role, for more than a third of them, in their final choice of a course of study or type of work.

Another indication can be found in a study by Gijselaers and Ramaekers (1991) among second year economics students at the University of Limburg. This research shows that the choice of their 'major' - i.e., whether to graduate in general economics, business economics or international management is largely determined by the desire to undertake an interesting course with which one can practise an occupation which is in itself interesting. Other factors which played an important role in the choice were the possibility of choosing from a broad range of occupations with a particular qualification, and that graduates in the field have a high probability of getting a job. The income that can be earned is clearly less important. The quality and the degree of difficulty of the course also appear to play a less important role in the choice of study. Analogously, to some extent, to the studies by Willems and De Grip and by Pater, economics students were also asked about the image they had of the labour market. It was found that they were reasonably able to compare the labour market prospects of economists - in terms of employment and income - with those of graduates from other types of university education.

These research results indicate that students apparently pay considerable attention to the labour market when they are deciding whether to study further, and that they are also able to form a general picture of their perspectives on the labour market with the further education which might be involved. It is hardly surprising that the picture which they have is not always accurate, because the labour market data which has traditionally been available is incomplete and generally not suited for the choices which students must make. ${ }^{4}$ The data on registered unemployment, for example, does not include all those who are seeking work and have not found it, and the data is also far from 'clean' because some of those registered have already found work, although this is often temporary. Another very important limitation is that the data which was available until a few years ago generally related only to the past, but for those choosing a course of study it is the situation at the end of this course, thus a situation which has yet to emerge, which is relevant. This data is now available in the Netherlands from the reports of the medium-term forecasts which ROA has been making since the late 1980s. These forecast the labour market prospects of types of education, covering the full width of the labour market. These reports are in fact becoming increasingly popular in the field of

4. The points on which the images which students have correspond with, and differ from, reality are discussed in ROA (1995), Chapter 5. 
vocational and educational guidance, but their specific impact on the quality of the educational and vocational choices of students in secondary and higher education has not yet been evaluated.

A good supply of information as regards the labour market is important for secondary and tertiary students. The availability of good labour market information can in fact not only benefit the choice of a study or occupation, but can also contribute to reducing the gap between expectations and the reality after graduation. It would produce a better allocation of secondary and tertiary students to the various types of education, in the sense that fewer of those making study choices would mistakenly undertake courses because they have an excessively optimistic idea of the opportunities they offer in the labour market, and also that fewer would mistakenly avoid courses of further education which appear to them to be associated with unfavourable labour market signals. ${ }^{5}$ The ROA reports, which are primarily designed to assist students in their vocational and educational choices, are also intended to improve the labour market allocation processes in this sense.

\subsection{For other interested parties}

In addition to secondary and tertiary students, educational institutes, employment services, the government and trade and industry have an interest in the availability of labour market information. Educational institutes, and perhaps even more their most important financier, the government, want the education which is provided to produce a social return of a certain level. Part of this is that the qualifications which are awarded should have some useful applicability in the labour market. They will try to avoid a situation in which, on the one hand, funding is maintained for educational facilities which offer types of education with which it will later be difficult to get work while, on the other hand, there is insufficient room for the expansion of types of education characterized by favourable labour market prospects. The employment services have an interest in seeing that the education system, in terms both of content and the allocation of students between the various types of education, contributes to minimalizing unemployment and seeing that the available vacancies are appropriately filled. For trade and industry, it is important that there is a sufficiently large potential workforce to fill the available work places, and that the workers who are recruited have the specific knowledge and skills to enable them to produce the highest possible productive performance.

These interests are in part already served by improving the allocation of students between the various types of education, by making labour market data available which gives a realistic picture of the possibilities on the labour market. But the various institutions which carry out policy, if they are to make plans to achieve their objectives as regards the labour market, will also have a direct need for labour market information. The institutions which execute an educational or training policy are interested mainly in the availability of information on changes in employment levels and on the replacement demand, differentiated by function or occupation, and the educational prerequisites for employment in these posts. The interests of trade and industry, and the government as an employer, will focus mainly on the flows from the various elements of the education system onto the labour market, and on the knowledge and skills which this new labour supply has, in relation to the specific demands which they will meet in carrying out their work. The institutions which are involved in carrying out labour market policies will mainly need information on current and threatened discrepancies between the flows coming from the various types of education into the labour market and the need for new workers as a result in changes in employment levels in the various segments of the

5. For a fundamental analysis of this problem, see Borghans (1993). 
labour market.

As we have already seen in relation to the labour market information for educational and vocational choices, the information which is required if the institutions named above are to be able to take measures to improve the match between the education system and the labour market is far from adequate. This is not surprising, because in both cases the information required is quite similar. The lack of a good supply of information means that putting a policy in place as regards the mutual tuning of the education system and the labour market could be compared with setting a course from an uncertain position for an equally uncertain destination, on a turbulent sea and in thick mist. Naturally a safe and certain course is a matter of chance rather than the rule.

An improvement in the supply of information, such as that which ROA seeks to realize in the Netherlands through its Information System on Education and the Labour Market, would make the labour market more transparent for both those choosing a course of study and for educational institutions, employment services, government authorities and trade and industry. It would enable them to give a more rational foundation to their decisions, and the result of the actions which they undertake would be qualitatively better as the result of having a more motivated workforce, higher productivity, lower unemployment and less hard-to-fill vacancies. This is emphatically not to say that improvements in the supply of information will bring utopia within reach. The world in which the improved labour market information must be placed is too uncertain and complex for an entirely certain position and a fixed and safe course ever to be achievable. The most that can be expected is a significant improvement in the current sub-optimal match between the education system and the labour market.

\subsection{More stable flows into the education system}

An improvement in the information on changes in demand and supply on the labour market would not only lead to a qualitatively better correspondence between the education system and the labour market, as described in the previous paragraph, it could also stabilize the flows of students entering the various types of education. This would occur if the labour market segments involved exhibit a more stable pattern, as compared to the current often highly variable educational preferences of students, and if these students, as a result of the availability of better labour market information, would be more influenced by the labour market prospects than is the case now. Greater stability would also result if there is a so-called cobweb cycle in students' educational preferences. This is a situation in which students base their educational choices on the labour market situation at the time they make their choice rather than on the labour market situation when they finish the chosen course. The self-sustaining dynamic process which results, and which will be described in more detail below, can be dampened by providing information on the future labour market prospects of types of education (there are certain conditions for this to work, which cannot be gone into here). ${ }^{6}$ This section will examine this potential stabilising influence of labour market information on the flows of students entering the various types of education in more detail.

Students' interest in a particular type of education is often very changeable, as noted above. Over time, a wave pattern can be seen in the flows of new students entering many types of education. This

6. See Borghans (1993), Chapter 15. 
oscillating pattern leads to uncertainty regarding the annual flows entering the various types of education. As would be expected, the educational institutes are therefore inclined to maintain a teaching capacity - in terms of people and facilities - which is somewhat greater than is strictly necessary, so as to be able to cope without difficulty with any unexpected increase in the inflow. In fact a higher average educational capacity would also be expected if these fluctuations were entirely predictable, because initiating and closing down teaching capacity entails adjustment costs. Any increase in the stability of the flows of new students would thus produce savings in the costs of education as a result of the greater predictability of the inflows and the reduced risk of having to meet adjustment costs.

Stabilisation of the inflows can also be favourable for the labour market, where students' study choices exhibit the cobweb cycle which was mentioned above. The cobweb cycle can be visualized using figure 1, taken from a study by De Grip (1987, p. 54). In the figure the flow of time is from top to bottom. The left-hand blocks relate to successive situations in the labour market. The right-hand blocks refer to the situations in the types of education concerned - in this figure a 4-year course for a skilled trade. The figure begins with a situation in which there is a shortage of tradesmen and, as a result, wages are high. This will lead many people to choose this particular course. At the end of the course the last-year classes will be large and there will be large flows of graduates entering the labour market. If the demand for these tradesmen has not changed significantly in the meantime, there will be an oversupply of labour in that part of the labour market and the wages will come under downward pressure. Now only a few people will choose this course. At the end of the 4-year training period, this will mean small classes of last-year students, and limited flows entering the labour market. The situation in the labour market has now returned to that at the beginning of the cycle, with a shortage of tradesmen and high salaries.

The cobweb cycle described in the figure shows why periods with large over-supplies of workers with a particular educational background can alternate with periods with large shortages of the same workers. It shows how adjustments in a labour market which is not in equilibrium, in the form of increased or reduced participation in education, can themselves lead to new disequilibria in the future. These dynamic disequilibria entail not only increased educational costs, as mentioned above, but also costs for social security benefits for the unemployed during periods of excess supply and losses of production during periods of shortages. There are thus potential advantages for society if these cobweb cycle oscillations in the flows entering educational courses can be countered.

From this description of the cobweb cycle, the factors which are responsible for the existence of a cobweb cycle in the education system can easily be deduced. In the first place, there must be a clearly defined sub-market for people with a particular kind of training. This is the case if the graduates from the type of education concerned look for work within a limited field and the workers in that field are recruited from among the graduates from that type of education. There is then an oneto-one relationship between the type of education and the relevant segment of the labour market. The second condition for the creation of a cobweb cycle is that the training lasts relatively long. The longer the course is, the larger the peaks and troughs of the cobweb cycle will be. The last important condition for the formation of a cobweb cycle is, as was noted above, that people who are choosing a course of study respond to the labour market situation at that time, rather than to the prospects as they will be when they have completed the course.

This summary of the causes implies that it should be possible to dampen the cobweb cycle oscillati- 
ons by:

- making the training broader, so that a larger employment field can be commanded with that type of education. However such a broadening has to be limited if the course is to continue to offer a credible level of expertise in the occupation concerned. Excessively radical broadening of the training may in fact be at the price of reduced productivity in practising the occupation, so that the market value of the course is reduced;

- shortening the formal study. There are also limits to this modification. In fact, if quality is maintained by not reducing the course contents in proportion to the shorter time, less students will be able to successfully complete the course and the drop-out rate will rise;

- providing high-quality information, before students undertake the course, on the situation which may be expected in the labour market at the end of the training period. This needs to relate especially to the future level of employment in the relevant labour market segment, as compared to the expected flows coming from the education system. This solution also has its limits, since forecasts are never perfect and must generally be hedged about with generous margins for uncertainty. ${ }^{7}$

Figure 1

Cobweb cycle in a sub-market, for a 4-year course

Market situation

Training situation

\begin{tabular}{|c|c|c|}
\hline $\begin{array}{l}\text { year } \\
1-4\end{array}$ & $\begin{array}{l}\text { high wages; } \\
\text { shortage of tradesmen }\end{array}$ & $\begin{array}{l}\text { many people choose this } \\
\text { course }\end{array}$ \\
\hline & $\begin{array}{l}\text { wages under pressure; } \\
\text { over-sunoly of tradesmen }\end{array}$ & large last-year classes \\
\hline & & $\begin{array}{l}\text { few people choose this } \\
\text { course }\end{array}$ \\
\hline $\begin{array}{l}\text { year } \\
9-12\end{array}$ & $\begin{array}{l}\text { high wages; } \\
\text { shortage of tradesmen }\end{array}$ & small last-year classes \\
\hline
\end{tabular}

Source: De Grip (1987)

\section{Labour market theory and labour market information}

7. For a simulation of the effects, for the labour market, of an increase in the transparency of the labour market for those choosing a course of study, see Heijke and De Grip (1995). 


\subsection{Various theoretical visions}

The transparency of the labour market cannot be increased by the aimless collection of labour market data. In order to choose the relevant information and to be able to interpret it correctly, it is necessary to have some understanding of the functioning of the labour market. However there is no one generally accepted way of looking at the functioning of the labour market. Differences in theoretical principles lead to differing needs for new labour market information, and open up a range of possible interpretations of the information which is already available. Some people emphasise the flexible character of the relation between education and the labour market. In this conceptualization, disequilibria in the match between the education system and the labour market are dealt with through the supple working of wage adjustments and substitution between types of education. Other people emphasise the unbalanced and rigid character of the relation between education and the labour market. They see the labour market as strongly segmented, and put no faith in the supple working of the wage mechanism.

The answer that the truth may well lie somewhere in between sounds plausible, but does not give sufficient insight into the specific manner in which the coordination between the education system and the labour market comes about. Therefore this section will examine in more detail a number of specific ways of seeing the relation between education and the labour market which are found in the standard literature. These views of the specific manner in which the match between the education system and the labour market is established offer interesting starting-points for answering the question of what information is relevant for evaluating the opportunities open to people with particular types of education in the labour market. As mentioned above, they also offer different visions as to the credibility of the supple working of the labour market. We will first examine the human capital theory, then the screening hypothesis, the labour queue theory, the job matching theory and last of all the segmentation theory.

\subsection{Human capital theory}

According to the human capital theory, people have productive skills, which they can increase by investing in themselves (Schultz, 1961). They can do this by undertaking education, caring for their health, or switching to a better job. The theory of human capital focuses especially on investment in human productive capacity through education and training. Education and training provide knowledge and skills which can be of use in practising an occupation later, and can thus productively be employed on the labour market.

The theory of human capital is grounded in the neo-classical economic school. This school talks about perfectly functioning markets, which are all in equilibrium. The labour market is also in equilibrium, the wage mechanism is supple and all unemployment is voluntary. In 
this situation the returns to labour are equal to the marginal productivity of labour. If an individual has increased his productivity by undertaking extra education and then enters employment, he will thus receive a higher wage than if he had gone directly to work without training. But these benefits in the form of extra income must be balanced against the costs, in the form of sacrificed income during the course and the direct expenditures on course fees and study materials.

As with every investment, the benefits and costs each relate to a different time period. If they are to be compared with each other, they must be expressed in terms of present cash value. Future amounts will then have a lower value than the same amounts in the present. In determining the present value of these amounts, a discount rate must be used. This rate expresses the extent of the preference for current income as compared to future income, which is why it is also called the relative time preference of the individual. If the capital market, like the labour market, functions perfectly and is in equilibrium, the discount rate is equal to the interest rate in the capital market.

Individuals will consider their personal capacities, and choose types of education for which the present value of the benefits is higher than the present value of the costs. If more individuals choose a particular type of education, the benefits from that course will fall because the increasing supply entering the labour market will lead to lower wages. Ultimately an equilibrium will be achieved. The ratio of benefits to costs which, according to the theory of human capital is the guideline for the training decisions of the individual, is thus not a given fixed for all time, but is itself dependent on the training decisions which are made. However this is a market result deriving from the educational choices which are made. For individuals, the existing cost-benefit ratio (the return to training) is always a given which cannot be affected.

The human capital theory can be summarized using figure 2, which is derived from Hamermesh and Rees (1984, p. 60). In this figure, the vertical axis shows the costs and benefits and the horizontal axis is the age of the individual. The line BB reflects the income path if no further education is undertaken from the age of 18, and line AA shows the costs which would be incurred if, from that age, a four-year course of further education is taken, and also the pattern of wages after the completion of this education. The wage curve after completing the course naturally begins to rise later than the wage curve without this education, but rises more steeply and will cut curve BB after some time. Both wage curves angle downwards beyond a certain age because the productivity of the individual is then becoming less. However the wage curve with additional education (AA) remains above the curve without the education (BB). The education thus leads to permanently higher productivity for the individual. According to the human capital theory, the individual will choose to take the course concerned if the present value of the extra revenues resulting from the course (area 3 ) is greater than the present value of the sum of the training costs (area 1 ) 
and the sacrificed income during (and for a short time after) the course (area 2). ${ }^{8}$

Figure 2

Investing in a training course

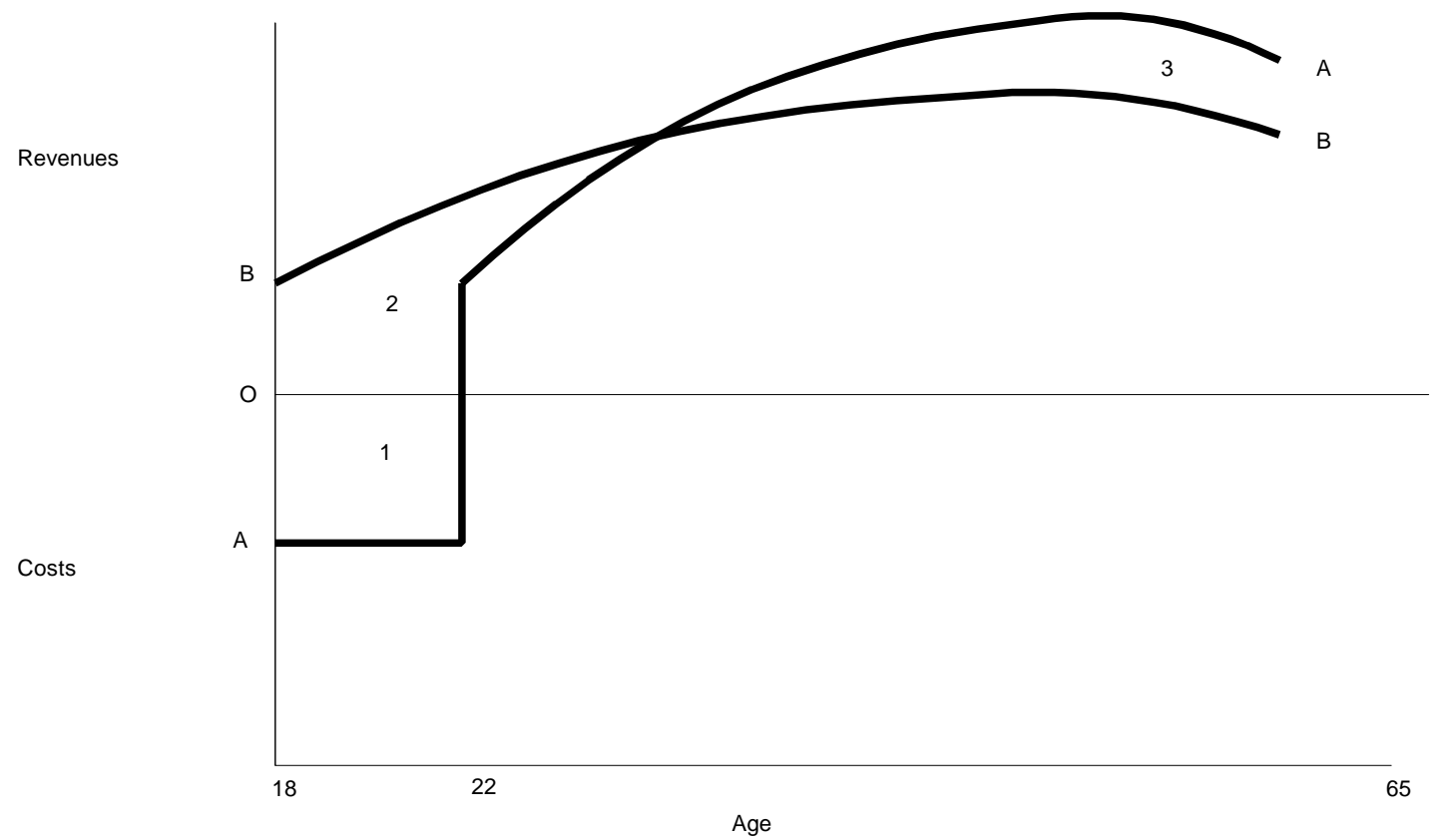

Source: Hamermesh \& Rees (1984)

\subsection{The screening hypothesis}

The human capital theory has not escaped criticism. A contrasting approach has developed which has come to be known as the screening hypothesis (Stiglitz, 1975). According to this idea, education does not create new productive skills. A diploma only proves that someone has the skills to earn that diploma, such as a certain measure of intelligence and learning ability, the ability to complete the tasks which were set, and stable behaviour patterns. The diploma therefore provides employers with a good selection criteria, enabling them to establish how talented workers are. The higher the diploma, the more talented and thus the more productive the individual may be assumed to be. According to the signalling theory variant (Spence, 1973) individuals exploit this by choosing a type of education which will make their virtues visible to employers. The diploma is thus no more than a signal to

8. The present value formula in this example would be: $P V=\sum_{i=18}^{65} \frac{Y_{i}^{C}-Y_{i}^{h}}{(I+r)^{i-18}}$ in which $\mathrm{PV}=$ present value at age $18 ; i=$ age; $y^{c}=$ net revenue if the course is taken; $y^{h}=$ net revenue if no further education is undertaken; $r=$ market rate of interest (see Hamermesh and Rees, 1984, p. 62). 
employers that particular personal qualities, which are useful in practising a profession, are present in the individual concerned. The knowledge and skills gained during the training are thus not important for the employer. Employers will therefore reward the achievement of a higher diploma with higher wages, but will not attach any significance to training courses which have not been completed. In the event that a course is abandoned, the wage will be appropriate to the diploma which was gained in the previous educational phase.

It is clear that, if signalling theory or the screening hypothesis have any validity, the education system is nothing more than a very expensive selection mechanism, which may well be efficient in providing information on the practical capacities of individuals, but does not itself add any extra qualities to the initial capacities. In both the human capital theory and the screening hypothesis, wages are determined by the level of the educational qualifications which have been obtained. In the screening hypothesis it is in fact only the possession of the diploma which is important in determining the wage level, while in the human capital theory education gained during courses which were not completed also raises productivity and is thus expressed in higher wages.

\subsection{The labour queue theory}

The labour queue or job competition theory (Thurow, 1975) assumes, like the screening hypothesis, that the knowledge and skills which are important in practising a job are not gained in the education system. The capacities required can only be obtained by training on the job. But this entails costs for the employer. In recruiting workers, the employer will therefore rank the candidates on the basis of the personal background characteristics such as age, sex and educational attainment - which are indicative of their trainability and thus of the training costs which will be required. The workers who are most highly ranked will be the first to be hired.

According to this theory, marginal productivity, and thus also wages, are determined by the characteristics of the job and not by the characteristics of the worker. Wages are therefore not determined by qualities which workers have gained from the education system or which are made visible by that system. The wage structure is, for them, a given. Individuals can try to gain a higher income by getting higher diplomas, which place them higher in the labour queue and thus in a position to gain higher, and thus better-paid, jobs.

If there is any truth in this theory, an educational race can easily arise, in which people try to get ever higher diplomas in order to get closer to the front of the labour queue. If everyone tries to do the same there will be "diploma inflation", with those with a lower educational level being displaced from their traditional occupational domains by people with higher-level education, without any change in comparative wages. The massive rise in the rate of participation in education will thus not lead to higher social productivity, while educational expenditures will go through the ceiling (cf. De Grip, 1987, p. 63). However the 
trainability of the workforce will increase and the costs of continuing training will therefore fall.

\subsection{The job matching theory}

The job matching theory (Sattinger, 1975; Jovanovic, 1979) supposes that the abilities of individuals do not give them any absolute advantages for employment in any possible job. On the contrary, their productivity is partly determined by the specific demands which particular jobs entail. The productivity of an individual thus depends on both his or her abilities and on the characteristics of the specific position that individual holds. The individual can utilize comparative advantages by applying his or her knowledge and skills in the portion of the labour market where these are the most productive. One consequence is that, in contrast to the human capital theory, the knowledge and skills acquired in the education system are not rewarded with the same wages wherever in the labour market they are used. The job in which they are applied is, in fact, also important.

The job matching theory also supposes that the information available in the labour market about both the skills required in various jobs and the skills which workers have is inadequate. The heterogeneity and opacity on both sides of the labour market make it more difficult to achieve a perfect match between the characteristics of the employees and of the jobs they perform. Workers will only get a true picture of their productive capabilities once they are actually at work in a job. School-leavers' entry to the labour market may therefore involve a process of searching for the optimal job, leading to repeated job-switching, or 'job shopping' (Topel and Ward, 1992).

\subsection{The segmentation theory}

The segmentation theory has become well-known for the development of the concept of a 'dual labour market' (Doeringer and Piore, 1971). According to this concept, the labour market can be divided into two segments, and the allocation mechanisms in the two segments are different.

The primary segment covers larger enterprises producing for a stable product market. These enterprises operate according to clear plans and employ capital-intensive production methods. This segment offers well-paid jobs with attractive career paths. Mobility is in this segment normally vertical, and upwards, and generally takes place within the same enterprise. Within these internal labour markets, rules and procedures determine the allocation of personnel to functions and their further advancement. The workers in this segment have characteristics which give them a strong market position: they are more likely to be well-educated and male, to have a good social background, and not to be members of ethnic minorities. 
The secondary segment, in contrast, is characterized by smaller and weak businesses producing for less certain markets. The jobs in this segment are at a low level, poorly-paid, and with few prospects. Mobility is horizontal, and it is not possible to advance to the primary segment. This segment provides jobs for workers with a weak labour market position: those with poorer education, young people, women and members of ethnic minorities.

\section{What labour market information is required?}

Each of the theories which have been discussed implies a different emphasis in the data which would have to be collected in order to gain an impression of the labour market possibilities offered by particular types of education. The human capital theory emphasized the importance of collecting wage data for people who have a particular educational background, so that the returns to education of this type can be established. According to this theory, it is important to ascertain not only the wages of those who have gained the diploma, but also of those who stopped that course prematurely, because every year of education which has been completed increases the productive powers of the individual. But according to the screening hypothesis there is no point in collecting wage data for those who have dropped out of the training, because according to this theory it is only the actual possession of the diploma which counts. This theory would point to the need for information on the probability of successfully completing the course.

Both theories assume a supple labour market, although this is segmented by types of education. This assumption is hardly realistic, since one generally finds in practice a rigid wage structure and limited elasticity of demand and supply. This means that the labour market is characterized by disequilibriums, so that demand and supply in the various secondary markets are not necessarily equal to each other. The probability of finding a job after having completed an educational course is thus not always equal to one, and the resulting unemployment - often temporary - is generally not voluntary. Because of this limited job choice, the income that is associated with the jobs which a particular type of education is aimed at is temporarily beyond reach. Thus it is important to gather data on the probability of finding a job with particular types of education, and to correct the data on the return to these types of education to allow for the income effects of periods of unemployment during a working life.

The probability of finding a job should relate to those leaving their initial education, i.e., to newcomers on the labour market. Their employment chances are determined by the ratio between the job openings for newcomers to the labour market and the inflows of schoolleavers from initial education entering the labour market. To be able to determine the probability of finding a job, it is necessary to have data not only on the flows coming from the various types of education to the labour market, but also information differentiated by 
types of education on the expansion demand and the replacement demand, which together determine the number of job openings. It should be noted that labour market discrepancies are now being called 'probabilities of finding a job'. If we were looking at this in terms of the demand side of the labour market, the reference would be to the probability of finding a worker.

The labour queue theory highlights the limited significance which wage information has for determining the benefit which can be derived from undertaking a course. The level of the job which is eventually won has, according to this theory, a dominant influence on the level of remuneration. Those making study choices and wanting to determine what their future income would be with a particular qualification, need first to estimate their later probability of finding a job, which is dependent on their relative position in the labour queue at the end of the course. It is thus important for them to have not only data on how well paid jobs are, but also information on the educational decisions of their fellow students. There are also a number of mechanisms which are discussed in connection with the labour queue theory: such as the phenomenon mentioned above of the displacement from their occupational territory of people with lower-level education by those with higher education, and the overschooling which results. If, despite this theory, one believes in the productive significance of education, these mechanisms would point to fundamental problem situations on which one would have to gather data. It would then be necessary to have information on the level of jobs in relation to the educational level of the people holding these jobs, and on the changes in these levels over time.

The matching theory makes it clear that information on the level of jobs is not in itself sufficient: it is also necessary to make information available about the characteristics of these jobs and especially what knowledge and skills (operationalized in the form of educational background), provide comparative advantages for people in these jobs. Furthermore, school-leavers should have some insight into what knowledge and skills relevant to the available jobs they themselves have. Since the knowledge and skills required are differentiated by occupational categories, while the knowledge and skills available are differentiated by educational categories, providing labour market information differentiated by occupation and education is already an important step in the direction of making the labour market transparent for those facing educational choices.

In view of the fact that there are segments within the labour market with differing allocation mechanisms offering differing career prospects, a more detailed differentiation of these occupational categories would be desirable. From the description of the segmentation theory, it follows that businesses can be divided over the two segments on the basis of the size of the enterprise, the stability of the market for which they produce and their capital intensity. Because the factors of market stability and capital intensity differ very much by 'branches of industry', as these are defined in the statistics, application of the segmentation theory would imply that the occupations should be divided by business size and branch of 
industry. Finally, to trace the labour market prospects of groups which have a weak position on the labour market, and are very much reliant on the secondary segment, it is important that the supply should be differentiated by educational level, age, sex and ethnic minority status.

\section{Labour market forecasts}

\subsection{Basic principles}

The labour market information referred to above would have to be forecast data, because the benefits of educational investments only appear in time. But making labour market forecasts is anything but simple. However, on the basis of past experience, embodied in the approach which is followed in ROA's Information System on Education and the Labour Market, we can suggest a number of principles which may be kept in mind when compiling labour market forecasts which are differentiated in detail for economic sectors, occupations and training types.

- The forecasts must be limited to the medium term, that is, to a period of about five years. Within this horizon the changes on the labour market are less uncertain than in the long term, where the uncertain results of the emergence of substitution and other adjustment processes can be decisive, especially where the discrepancies between demand and supply may be extremely large. A forecast period of five years is moreover sufficiently long to produce useful labour market information for those who are investing in a course which will last for a number of years.

- In place of fixed coefficients for the occupational and training structure of employment, explanatory models must be used to describe the changes in both structures over time. This should also be attempted as regards the flows within the education system and the participation of graduates in employment. The forecasting models would then be more theoretically justifiable, which would make forecasting with these models less of a black box affair.

- No detailed comparisons of demand and supply must be made for each forecasting year, but the forecast itself must be limited to giving a general characterization of the relation between demand and supply for broad categories of training over the whole forecast period. Information intended as guidance for students can be limited to a qualitative description of the labour market prospects of these training categories, on a scale from 'good' to 'poor'. This requires that the training categories be carefully constructed, so that the variation in labour market prospects within each category is as small as possible. The use of qualitative descriptions will prevent the quantitative forecasts being treated as more precise than is really the case.

- The forecasts should be repeated within a period of a few years. A forecast every other 
year is frequent enough to keep a finger on the pulse, while leaving sufficient time to evaluate the observed differences between forecasts and the results realized in the market and to use these evaluations to improve the forecasting method. The differences between forecasts and realizations do have a certain tendency to increase over time. Waiting too long to make modifications will not only encourage bad decisions on training and education, the visible mistakes in forecasting will also contribute to a negative image of the value of labour market forecasts.

- It is important to make as much use as possible of any understanding which already exists of the future growth of employment and the flows from the education system onto the labour market. In the Netherlands this applies especially to changes in the employment in economic sub-sectors, which ROA takes from the Central Planning Bureau, and to the flows from the education system onto the labour market, which are largely taken from forecasts made by the Ministry of Education, Culture and Science. Another suggestion is to create a network of contacts with centres of sectoral expertise which are capable of giving high-grade information or feedback on specific elements. The elaboration and specification of these sources must of course be done in a theoretically justifiable and consistent manner.

- The uncertainties which are associated with labour market forecasts can to some extent be met by mapping the labour market risks which a particular choice of training may entail, as a supplement to the forecast of the probability of finding a job. Statistical indicators can be developed for, for example, the opportunities which a type of education offers of switching between occupations and the sensitivity of the occupations which are relevant for a particular type of education to the state of the business cycle. ${ }^{9}$

\subsection{ROA's approach}

By way of illustration, this subsection will describe the approach which ROA applies in compiling the forecast data in the Information System on Education and the Labour Market (see ROA, 1995). Under this approach, forecasts are made of the flows entering and leaving the labour market in a particular future period. This approach has the advantage of showing the processes that are important for the development of demand and supply in the labour market.

Figure 6.1 gives a schematic overview of the forecasting model used in the information system for education and the labour market. ${ }^{10}$ One flow volume which is important for the demand side of the labour market is the expansion demand, which reflects the movement in employment levels in a particular occupational class or for a particular type of education. The forecasts of expansion demand are based on the employment level forecasts for economic sectors which are produced by the Dutch Central Planning Bureau. Because

9. For these risk indicators see: De Grip and Heijke (1988).

10. A comprehensive explanation can be found in De Grip, Borghans and Willems (1995). 
particular occupational classes within an economic sector grow more rapidly than others, ROA translates these changes in the economic sectors into the expansion demand per occupational class. Then the implications of the predicted growth in the various occupational classes for the expansion demand for each type of education are determined. An allowance is made at this point for any shifts which may be occurring in the educational structure of occupational classes. The expansion demand per type of education refers to the number of people with a particular educational background that employers would like to be able to employ. The actual change in employment levels per type of education will Figure 6.1

General structure of the forecasting model for ROA's information system for education and the labour market 


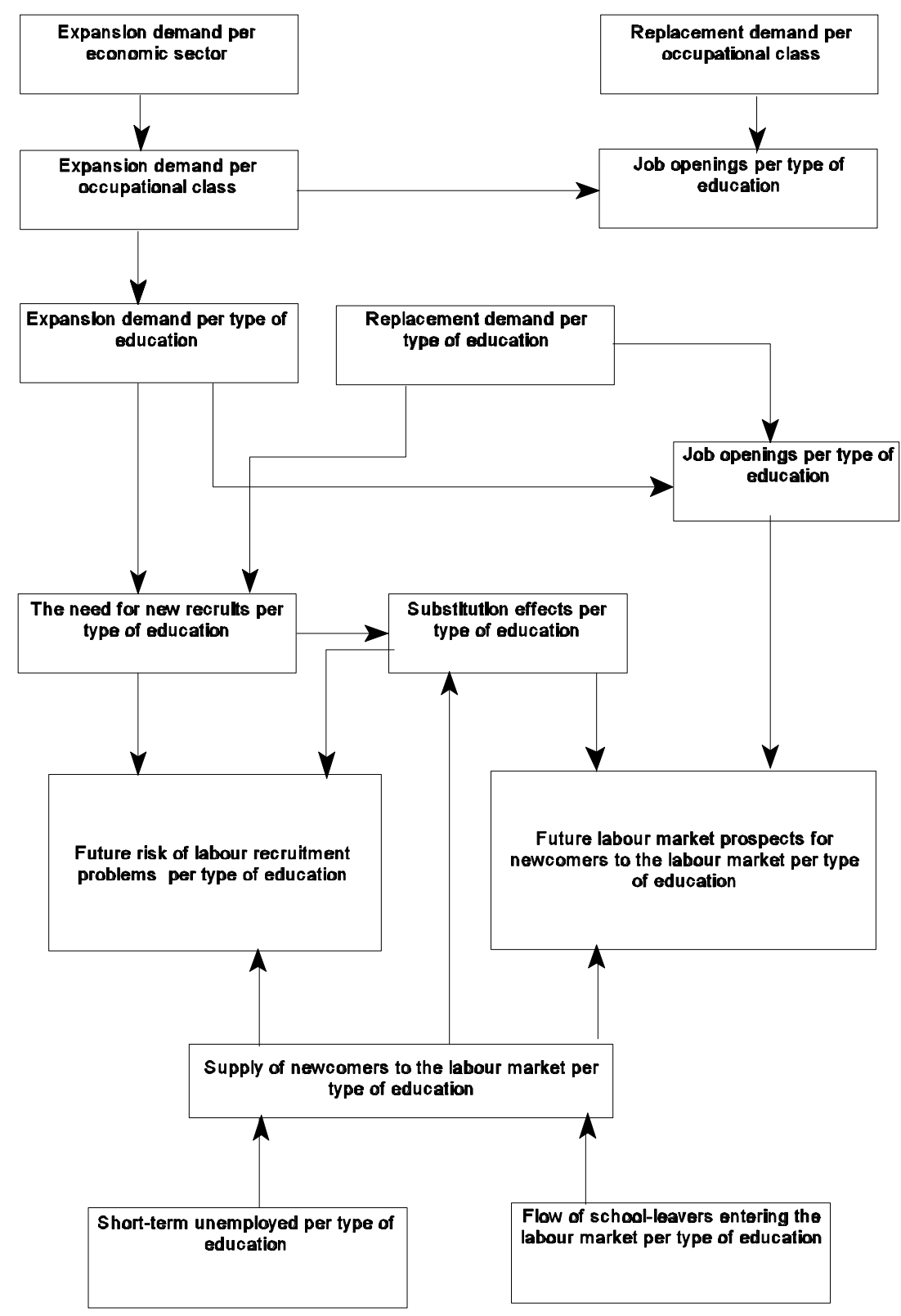

generally differ from this because changes on the supply side affect relative scarcities and lead to substitution processes. 
Demand on the labour market consists not only of expansion demand, but also of replacement demand, which arises when workers retire, leave the labour force under the early retirement scheme or due to work disability, withdraw from the labour market temporarily, or switch to another occupation etc. However replacement demand only arises if the departure of an employee actually leads to a vacancy for a new entrant. If the departure of a worker is taken as an opportunity to cut employment levels, no replacement demand results. These flows out of the labour market are in fact irrelevant for newcomers. Thus only part of the flows leaving the market generate replacement demand. Moreover, there is an important difference between the replacement demand per occupational class and per type of education, because occupational mobility has an influence on the replacement demand per occupational class, but not on the replacement demand per type of education. Switching occupations has no effect on the educational structure of employment.

If employment levels are rising, the expansion demand and replacement demand together comprise the job openings for newcomers to the labour market. If employment levels are declining job openings can only arise due to replacement demand.

In the labour market, the total demand for newcomers confronts the expected supply of newcomers, which consists of the future flow of school-leavers entering the market during the forecast period and the supply of short-term unemployed waiting to enter the market at the start of this period. It is assumed that the long-term unemployed, who have been looking for work for longer than a year, no longer constitute serious competition for schoolleavers.

The forecasts of the flows of school-leavers entering the labour market correspond to the Referentieramingen 1995 (Reference forecasts) which are compiled by the Ministry of Education, Culture and Science for courses in the 'regular' (i.e., full-time initial) education system. ROA disaggregates these forecasts, and supplementary data is used to estimate the effects of the flows from non-regular education on the educational makeup of the flows entering the labour market. An allowance has also been made for the expected abolition of compulsory military training.

An indication of the future labour market prospects for newcomers to the labour market is derived, for each type of education, by confronting the expected flows of demand and supply with each other. This indicator shows what discrepancy may be expected between the demand and supply for each type of education. But excess supply does not imply that the group in question will as a matter of course become unemployed, and a supply shortfall does not automatically mean that there will be unfilled vacancies. In practice, it appears that school-leavers with a type of education for which the supply exceeds demand do suffer from a deterioration of their position, for example because they are more likely to have to accept work below their level, get less favourable contracts, are less well paid or more likely 
to work part-time involuntarily. ${ }^{11}$ In such a situation, employers would normally modify their demands and recruit people with a higher educational background than was originally contemplated. On the other hand, if there is a supply shortage the position of schoolleavers will improve, and they will then not have to accept a job at a lower level, for lower wages, etc.

Because of substitution processes, there will be less job openings for those with the types of education which suffer from 'crowding-out' by types of education with an excess supply. On the other hand, for those with educational backgrounds which are closely related to types of education which are in short supply, there will be extra job openings. These passive substitution effects are thus important determinants of the labour market prospects of types of education.

The confrontation between demand and supply also gives an indication of the future risk of labour recruitment problems for each type of education. The expansion and replacement demand jointly determine the recruitment requirement for each type of education. If employment for a particular type of education is declining, this recruitment requirement is calculated in a somewhat different manner than the number of job openings for newcomers to the labour market, because from the employers' point of view it is possible to achieve part of the retrenchment by limiting their recruitment, so that fewer of the existing personnel have to be dismissed. Employers will be especially likely to use this option when they face a tight labour market for a particular type of education.

Finally, qualitative characterizations are assigned to the expected developments on the labour market. This characterization makes it possible to quickly interpret the relative magnitude of any particular change in indicators such as the number of job openings, the supply of school-leavers or discrepancies between the job-openings and the number of school-leavers, without attributing too much weight to slight differences between the precise figures which show these movements. ${ }^{12}$

From this outline of the forecast approach which ROA applies in its Information System on Education and the Labour Market, it can be seen that it includes almost all the variables which were listed in section 5 as being informative for educational investment decisions. One exception is wage information, but there is insufficient basic statistical information available in this regard ${ }^{13}$. Various theoretical approaches can be recognized in the forecast-

11. For an empirical analysis of market adjustments of this type, see Wieling and Borghans (1995).

12. See Wieling, De Grip and Willems (1990) for an explanation of the way in which these characterizations are determined.

13. Information on sex and etnic minority status was not mentioned too, but is still available in the information system, see ROA (1995). 
ing methodology which is employed, but the overall approach most closely resembles the philosophy behind the job matching theory. One striking additional element is that the ROA forecast approach makes allowance for the existence of disequilibria and sub-optimalities in the labour market, which certainly makes this approach more realistic.

\section{A European approach}

The increase in the transparency of the labour market which is the goal here should preferably be achieved in a European framework, for a number of reasons. First, the market for those with higher education in particular is becoming ever more international, so that the labour market prospects which are forecast should increasingly relate also to the opportunities in other countries. Second, increasing European integration will mean that national borders, which have provided the dividing lines between neighbouring regional labour markets, will become increasingly indistinct. Thus it is becoming ever more relevant to incorporate neighbouring regions in the labour market forecasts for one's own country. A third reason is that the need to optimalize the match between the education system and the labour market is a problem which is to a large extent similar for all the EU countries. The member states must avoid separately re-inventing the wheel in the development of applicable instruments to increase the transparency of the future labour market. It is thus very important to encourage the exchange of information between the member countries regarding applicable models and methods, the data systems to be developed and the serviceability of the approaches which have been tried. The collection of papers describing the work of the leading European institutes for labour market research edited by Heijke (1994) may serve as an example of such an interchange of experience.

\section{References}

Blaug, M., 1967, Approaches to Educational Planning, Economic Journal 77 (June), pp. 262-287.

Borghans, L., 1993, Educational Choice and Labour Market Information, dissertation University of Limburg, Research Centre for Education and the Labour Market, Maastricht.

Doeringer, P.B. and M.J. Piore, 1971, Internal Labor Markets and Manpower Adjustments, D.C. Heath, Lexington, Mass.

Gijselaers, W.H., and G. Ramaekers, 1991, Studiekeuzegedrag als functie van onderwijsaanbod en arbeidsmarktontwikkelingen, in: W. Smit (ed.), Aansluiting en studievaardigheid, Amsterdam, pp. 66-78.

Grip, A. de, 1987, Onderwijs en Arbeidsmarkt: scholingsdicrepancies, thesis, Free University of Amsterdam, VU-uitgeverij, Amsterdam.

Grip, A. de, and J.A.M. Heijke, 1988, Labour Market Indicators: an Inventory, ROA-W- 
1988/1E, Maastricht.

Grip, A. de, and J.A.M. Heijke, 1991, Uitwijkmogelijkheden op de arbeidsmarkt; flexibiliteit versus produktiviteit, Onderzoek van Onderwijs 20 (February), pp. 6-8.

Grip, A. de, L Borghans and E. Willems, 1995, Methodology of the ROA information system on occupational groups and types of education, ROA-W-1995/1E, Maastricht.

Hamermesh, D.S., and A. Rees, 1984, The Economics of Work and Pay, New York, Harper \& Rowe, (3rd edition).

Hartog, J., 1985, Earnings Functions, Testing for the Demand Side, Economics Letters 19, pp. 281-285.

Heijke, H. (ed.) 1994, Forecasting the Labour Market by Occupation and Education. Boston Dordrecht and London, Kluwer Academic Publishers.

Heijke, H., and A. de Grip, 1995, Mismatches Between Education and the Labour Market, in: T. Jaspers, J. Schippers, J. Siegers and I. van Berkel (eds), Working Policies?, Facts, analyses and policies concerning employment and non-participation in the Netherlands, Wolters-Noordhoff Groningen, pp. 51-80.

Herweijer, L.J., and J.L.T. Blank, 1987, Onderwijsexpansie en werkloosheid, Tijdschrift voor Arbeidsvraagstukken 3, pp. 80-86.

Hoof, J.J. van, and J. Dronkers, 1980, Onderwijs en Arbeidsmarkt. Van Loghum Slaterus, Deventer.

Jong, U. de, H. Oosterbeek, J. Roeleveld, and H.D. Webbink, 1992, Verder studeren, voornemens van eindexamenkandidaten 1991, Ministerie van Onderwijs en Wetenschappen.

Jovanovic, B., 1979, Job Matching and the Theory of Turnover, Journal of Political Economy 87 (5), pp. 972-990.

Kodde, D.A., and J.M.M. Ritzen, 1986, Vraag naar hoger onderwijs, eindrapport, Beleidsgerichte studies Hoger Onderwijs en Wetenschappelijk Onderzoek, Ministerie van Onderwijs en Wetenschappen, ‘s-Gravenhage.

Koning, J. de, and A. Gelderblom, 1992, Age, Productivity and Wages, paper, EALE Conference September 3-6. Institute for Employment Research, University of Warwick, Coventry.

Koopmans, C.C., R. van Opstal and J.J.M. Theeuwes, 1989, Human Capital and Job Levels, European Economic Review 33, pp. 1839-1849.

Mincer, J., 1974, Schooling, Experience and Earnings, National Bureau of Economic Research. Columbia University Press, New York.

Oosterbeek, H., and D. Webbink, 1995, Enrolment in Higher Education in the Netherlands, De Economist 143 (3), pp. 367-380.

Parnes, H.S., 1962, Forecasting Educational Needs for Economic and Social Development. OECD, Paris.

Pater, L., 1987, Weg van school \& aan de studie, Ochtendblad Trouw, Amsterdam, pp. 4445.

ROA (Research Centre for Education and the Labour Market), 1995, The Labour Market by Ecucation and Occupation to 2000, ROA-R-1995/3E, Maastricht. 
Sattinger, M. (1975), Comparative Advantage and the Distribution of Earnings and Abilities, Econometrica 43 (3), pp. 455-468.

Schultz, T.W., 1961, Investment in Human Capital, American Economic Review 51 (1), pp. $1-17$.

Spence, O.F., 1973, Job Market Signaling, Quarterly Journal of Economics 87, pp. 355374.

Stiglitz, J.E., 1975, The Theory of 'Screening', Education and the Distribution of Income, American Economic Review 65, pp. 283-300.

Thurow, L.C., 1975, Generating Inequality, Basic Books, New York.

Topel, R.H., and M.P. Ward (1992), Job Mobility and the Careers of Young Man, The Quarterly Journal of Economics, May, pp. 439-479.

Verrijdt H., and J. Diederen, 1987, Determinanten van beroepskeuze, OSA-Werkdocument nr. W 39, Den Haag.

Wieling, M.H., and L. Borghans, 1995, Discrepancies between Demand and Supply and Adjustments Processes on the Labour Market, ROA-RM-1995/5e.

Wieling, M.H., A. de Grip and E.J.T.A. Willems, 1990, Een systematische kwalitatieve typering van arbeidsmarktinformatie, ROA-W-1990/8, Maastricht.

Willems, E.J.T.A. and A. de Grip, 1994, Young people and Technology, Beleidsstudies Technologie Economie 26a, Ministry of Economic Affairs, The Hague.

Willis, R.J., and S. Rosen, 1979, Education and Self-Selection, Journal of Political Economy 87, pp. S7-S36. 